\title{
New records and noteworthy lichens and lichenicolous fungi from Pasvik Reserve, Murmansk Region, Russia
}

\author{
Gennadii Urbanavichus ${ }^{1} \&$ Irina Urbanavichene ${ }^{2}$ \\ ${ }^{1}$ Institute of the North Industrial Ecology Problems, Kola Science Centre RAS, Akademgorodok 14a, Apatity, 184209, \\ Murmansk region, Russia. E-mail: g.urban@mail.ru \\ ${ }^{2}$ Komarov Botanical Institute RAS, Professor Popov Str. 2, 197376 St Petersburg, Russia. \\ E-mail: urbanavichene@gmail.com
}

\begin{abstract}
Sixteen species of lichens, five lichenicolous fungi and two non-lichenized fungi are reported for the first time for Pasvik Reserve (NW Murmansk Region). Clypeococcum hypocenomycis, Protoparmelia ochrococca and Xylographa vermicularis are new to the Murmansk Region and Xylographa vermicularis is new to Europe. Ten species are rarely recorded for Murmansk Region, European Russia or Russia: Arctoparmelia subcentrifuga, Chaenothecopsis debilis, Lathagrium undulatum, Merismatium nigritellum, Microcalicium disseminatum, Phaeophyscia nigricans, Placynthium asperellum, Protothelenella leucothelia, Stereocaulon capitellatum and Stigmidium leprariae. Fourteen species are new to the biogeographic province of Lapponia petsamoënsis. Two species, Arctoparmelia subcentrifuga and Stereocaulon capitellatum, are included in the Red Data Book of the Murmansk Region. Brief notes, mainly on habitats and distribution, are provided for all species listed.
\end{abstract}

Keywords: lichens; new records; diversity; conservation; distribution; North-Western Russia

\section{INTRODUCTION}

The Pasvik Reserve is important for the conservation of lichen diversity because it represents the northernmost mainly undisturbed forests for the whole of European Russia. Although there are numerous published articles on the lichen flora of Pasvik Reserve, the diversity of lichen-forming and lichenicolous fungi of this protected area is still underworked. The first list of lichens and allied non-lichenized fungi of Pasvik Reserve included 277 species (Fadeeva et al., 2011), since when additions have been made by Fadeeva et al. (2013), Urbanavichus (2014, 2015, 2016), Urbanavichus \& Fadeeva (2013, 2014, 2015, 2016, 2017) and Urbanavichus et al. (2014). The reserve supports this representative lichen flora requiring protection, and contributes to the development of rare epiphytic lichens and allied fungi. Within the Pasvik Reserve, habitat specialists (e.g. Bryoria fremontii, Chaenotheca chlorella, C. gracillima, Cyphelium karelicum, Hypogymnia vittata, Lobarina scrobiculata, Nephroma bellum, N. parile, N. resupinatum, Parmeliella triptophylla, Sclerophora coniophaea, Rostania occultata) and indicator species (e.g. Arthonia vinosa, Chaenotheca stemonea, Cladonia parasitica, Cyphelium tigillare, Leptogium saturninum, Melanelixia subargentifera, Microcalicium disseminatum, Ramboldia elabens) of biologically valuable forests in the
Southern Taiga of North-Western European Russia (Andersson et al., 2009) occur.

Based on the material collected in 20152016, 23 species are reported as new to the Pasvik Reserve, including Clypeococcum hypocenomycis, Protoparmelia ochrococca and Xylographa vermicularis which appear new to the Murmansk Region. As a result 482 lichenized species, 36 lichenicolous species and 8 saprobic fungi have been reported from the reserve. This is $41 \%$ of the lichens known from the Murmansk Region. Sixteen species are protected in the Murmansk Region (Red Data Book..., 2014): Arctoparmelia subcentrifuga, Arthonia vinosa, Blennothallia crispa, Bryoria fremontii, Chaenotheca chlorella, Chaenotheca gracillima, Chaenothecopsis nigra, Collema curtisporum, Dermatocarpon rivulorum, Lichenomphalia hudsoniana, Melanelixia subargentifera, Melanohalea exasperata, Phaeophyscia orbicularis, Ramalina subfarinacea, Stereocaulon capitellatum and Toninia verrucarioides.

\section{Study Area}

Pasvik State Nature Reserve (Zapovednik) is located on the right-hand side of Paz River (Patsojoki in Finnish, Pasvikelva in Norwegian), in the middle part of the valley, bordering boreal taiga and forest tundra (Borovichev \& Boychuk, 2016). The Reserve is part of the Pasvik-Inari 
Trilateral Park, which in addition to the four Norwegian protected areas includes Vätsäri Wilderness Area on the Finnish side of the border (Fadeeva et al., 2011). The western border of the reserve is identical to the Russian-Norwegian border. This territory belongs to the biogeographic province Lapponia petsamoënsis and Pechenga administrative district of the Murmansk Region of NW Russia. The territory of the reserve (c. $117 \mathrm{~km}^{2}$ ), situated 10 to $50 \mathrm{~km}$ from the town of Nikel, is on the northern margin of the Fennoscandian (Baltic) shield composed by ancient bedrocks (granites, granite-gneisses, gneiss, diorite, dacite, gabbro, amphibolites and schists with a high content of calcium oxide). The land, mainly covered by old-growth pine forest, intertwined with bogs, includes a tundra zone above $250 \mathrm{~m}$, and the highest elevation of the reserve is Kalkupya Mt. (357 m alt.). The climate is predominantly affected by the North Atlantic and the Polar arctic front. Northern winds are most common during summer, which can occasionally give snow in mid-summer. The mean temperature in January is $-10.4^{\circ} \mathrm{C}$ and in July $13.6^{\circ} \mathrm{C}$, and the mean annual precipitation is c. $500 \mathrm{~mm}$. There is "the midnight" sun from 23 May to 20 July and polar nights from 20 November to 23 January.

\section{MATERIALS AND METHODS}

Lichen collections were made by the first author in September-October 2016 (except for Thelocarpon superellum which was collected in 2015) mainly in previously understudied areas in the Pasvik Reserve; the material was microscopically studied together with the second author. Lichen substances were analyzed by standard technique of thin-layer chromatography using solvent systems A, B, and C (Orange et al., 2001). Cited specimens are deposited in the Herbarium of the Institute of the North Industrial Ecology Problems (INEP). The nomenclature follows Santesson's Checklist (http:/ / www.evolutionsmuseet.uu.se/databaser/santesson.html).

The following marks and abbreviations are used in the species list: ! - genera new to the Pasvik Reserve, \# - lichenicolous fungi, + - saprobic fungi, LPS - biogeographic province 'Lapponia petsamoënsis', MR - Murmansk Region.

\section{THE SPECIES}

Arctoparmelia subcentrifuga (Oxner) Hale Central part of the reserve, $32.5 \mathrm{~km} \mathrm{SW}$ of Nikel, 69 $17^{\prime} 22$ 'N, $29^{\circ} 27^{\prime} 19^{\prime \prime} \mathrm{E}$, cliffs on the left bank of the stream from Kaskamajarvi Lake to Bossojavrre Lake, on rocks, 01.10.2016. - This species is included in the Red Data Book for the Murmansk region (2014). The species was described by A. N. Oxner from NE Siberia in 1940; in MR it was previously reported from Kanadalaksha (Vitikainen \& Dudoreva, 2003), Lapland Reserve (Urbanavichus et al., 2013) and from the neighbourhood of the Pasvik Reserve (Urbanavichus \& Fadeeva, 2013). The species is characterized by its dark purplish or black lower surface and strongly rugose-pustulate or eroding upper surface (Fig. 1).

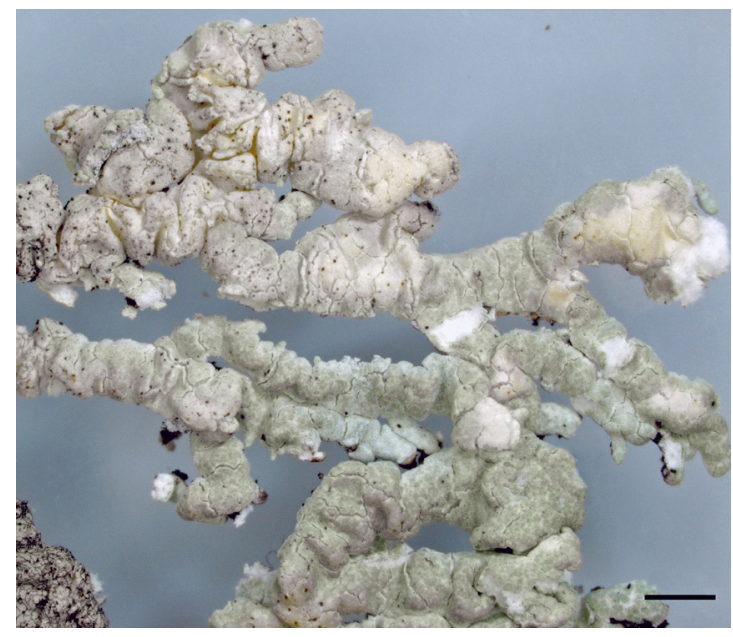

Fig. 1. Arctoparmelia subcentrifuga, upper surface of thallus. Scale bar $=1 \mathrm{~mm}$.

!\#Cercidospora epipolytropa (Mudd) Arnold - Northern part of the reserve, $17 \mathrm{~km} \mathrm{SW}$ of Nikel, 69² $1^{\prime} 04^{\prime \prime} \mathrm{N}, 2^{\circ} 48^{\prime} 35.5^{\prime \prime} \mathrm{E}$, young birch forest with willow, on apothecia of saxicolous Lecanora polytropa, 02.10.2016. - New to LPS. The species was previously reported in MR only from Lapland Reserve in Lapponia Imandrae (Urbanavichus \& Urbanavichene, 2008).

+Chaenothecopsis debilis (Sm.) Tibell - Central part of the reserve, $38 \mathrm{~km}$ SW of Nikel, $69^{\circ} 15^{\prime} 03.5^{\prime \prime} \mathrm{N}, 29^{\circ} 18^{\prime} 36^{\prime \prime} \mathrm{E}$, the eastern shore of Vouvatusjärvi Lake, the cape S of Kalkupya Mt., 
aspen forest, on bark of old aspen, 28.09.2016. - New to LPS. Formerly known in MR only from Kandalaksha Reserve (Zhdanov, 2011).

+Chaenothecopsis Pusilla (Ach.) A. F. W. Schmidt - Central part of the reserve, $40 \mathrm{~km}$ SW of Nikel, $69^{\circ} 15^{\prime} 35^{\prime \prime} \mathrm{N}, 2^{\circ} 17^{\prime} 35.3^{\prime \prime} \mathrm{E}$, northern part of Chevessuolo Island, pine forest, on free-living algae on lignum of pine snag, 28.09.2016. - The species has been rediscovered in LPS after 77 years (Räsänen, 1943). Rather widespread in MR (Urbanavichus et al., 2008).

!\#Clypeococcum hypocenomycis D. Hawksw. Central part of the reserve, $40 \mathrm{~km}$ SW of Nikel, $69^{\circ} 15^{\prime} 03.5^{\prime \prime} \mathrm{N}, 2^{\circ} 17^{\prime} 15.5^{\prime \prime} \mathrm{E}$, central part of Chevessuolo Island, old pine forest, on squamules of Hypocenomyce scalaris growing on pine lignum, 28.09.2016. - New to MR. The nearest locality in NW Russia is the biogeographic province Karelia Ladogensis in the Karelia Republic (Fadeeva et al., 2007) and in Finland is the province Ostrobottnia kajanensis (Nordin et al., 2011).

LATHAGRIUm Undulatum (Flot.) Otálora, P. M. Jørg. $\&$ Wedin - Central part of the reserve, 32.5 $\mathrm{km}$ SW of Nikel, 69¹7'22”N, 29²7'19”E, cliffs on left bank of the stream from Kaskamajarvi Lake to Bossojavrre Lake, on calcareous rocks, 01.10.2016. - Second record for MR. Previously known in MR and LPS only from Sredny Peninsula (former Stenpahta, Maattivuono) (Urbanavichus et al., 2008). The specimen reported as "Collema arcticum" by Räsänen (1943) has been re-determined as Collema undulatum by Teuvo Ahti (H).

LEPRARIA BOREALIS Lohtander \& Tønsberg - Southern part of the reserve, $39 \mathrm{~km}$ SW of Nikel, $69^{\circ} 14^{\prime} 24.4^{\prime \prime} \mathrm{N}, 29^{\circ} 20^{\prime} 51^{\prime \prime} \mathrm{E}$, NW-oriented slopes of unnamed mountain, on saxicolous bryophytes, 29.09.2016. - New to LPS. Previously known in MR from Khibiny Mts. and Lapponia Imandrae (Urbanavichus et al., 2008).

LEPRARIA FINKII (B. de Lesd.) R. C. Harris - Southern part of the reserve, $39 \mathrm{~km}$ SW of Nikel, $69^{\circ} 14^{\prime} 24.4^{\prime \prime} \mathrm{N}, 29^{\circ} 20^{\prime} 51^{\prime \prime} \mathrm{E}$, NW-oriented slopes of unnamed mountain, on saxicolous bryophytes, 29.09.2016. - Known (as L. lobificans auct.) from three provinces in MR: LPS, Lapponia Imandrae and Lapponia Varsugae (Urbanavichus et al., 2008).
LEPRARIA JACKII Tønsberg - Southern part of the reserve, $39.5 \mathrm{~km}$ SW of Nikel, 69 $15^{\circ} 03.5^{\prime \prime} \mathrm{N}$, $29^{\circ} 18^{\prime} 36^{\prime \prime} \mathrm{E}$, eastern shore of Vouvatusjärvi Lake, the cape S of Kalkupya Mt., aspen forest, on terricolous bryophytes, 28.09.2016; southern part of the reserve, $39 \mathrm{~km}$ SW of Nikel, $69^{\circ} 14^{\prime} 24.4$ "N, 29 20'51" E, NW-oriented slopes of unnamed mountain, on saxicolous bryophytes, 29.09.2016; central part of the reserve, $32.5 \mathrm{~km}$ SW of Nikel, $69^{\circ} 17^{\prime} 22^{\prime \prime} \mathrm{N}, 2^{\circ} 27^{\prime} 19^{\prime \prime} \mathrm{E}$, cliffs on the left bank of the stream from Kaskamajarvi Lake to Bossojavrre Lake, on saxicolous bryophytes, 01.10.2016. - New to LPS. Previously known in MR from Khibiny Mts. and Karelia Keretina (Urbanavichus et al., 2008).

LePraria Rigidula (B. de Lesd.) Tønsberg - Central part of the reserve, $32.5 \mathrm{~km}$ SW of Nikel, $69^{\circ} 17^{\prime} 22^{\prime \prime} \mathrm{N}, 29^{\circ} 27^{\prime} 19^{\prime \prime} \mathrm{E}$, cliffs on the left bank of the stream from Kaskamajarvi Lake to Bossojavrre Lake, on mosses over rocks, 01.10.2016. - In MR the species is rare, most probably under-collected, previously known only from LPS (Urbanavichus et al., 2008).

LePraRia vouauxi (Hue) R. C. Harris - Southern part of the reserve, $39 \mathrm{~km}$ SW of Nikel, $69^{\circ} 14^{\prime} 24.4^{\prime \prime} \mathrm{N}, 29^{\circ} 20^{\prime} 51^{\prime \prime} \mathrm{E}$, NW-oriented slopes of unnamed mountain, on saxicolous bryophytes, 29.09.2016; central part of the reserve, $32.5 \mathrm{~km}$ SW of Nikel, $69^{\circ} 17^{\prime} 22^{\prime \prime} \mathrm{N}, 2^{\circ} 27^{\prime} 19^{\prime \prime} \mathrm{E}$, cliffs on the left bank of the stream from Kaskamajarvi Lake to Bossojavrre Lake, on mosses over rocks, 01.10.2016. - New to LPS. Previously known in MR from Khibiny Mts. and Lapponia Imandrae (Urbanavichus et al., 2008).

!\#MERismatium NigRitelLum (Nyl.) Vouaux - Northern part of the reserve, $17.5 \mathrm{~km}$ SW of Nikel, $69^{\circ} 21^{\prime} 47.5^{\prime \prime} \mathrm{N}, 29^{\circ} 47^{\prime} 18^{\prime \prime} \mathrm{E}$, pine forest, on thallus of terricolous Protomicarea limosa, 02.10.2016. New to LPS. Previously known in MR only from Lapponia Murmanica (Zhurbenko, 2009).

Microcalicium disseminatum (Ach.) Vain. - Central part of the reserve, $40 \mathrm{~km}$ SW of Nikel, $69^{\circ} 15^{\prime} 35^{\prime \prime} \mathrm{N}, 2^{\circ} 17^{\prime} 35.3$ ' E, northern part of Chevessuolo Island, pine forest, on lignum of old pine stump, 28.09.2016. - New to LPS. This is the northernmost locality in European Russia. It is a southern species in MR, being previously known from Lapponia Imandrae (Urbanavichus et al., 2008) and Karelia Keretina (Zhdanov, 2011). 
PhaEophyscia nigricans (Flörke) Moberg - Southern part of the reserve, $42 \mathrm{~km}$ SW of Nikel, $69^{\circ} 12^{\prime} 40.2^{\prime \prime} \mathrm{N}, 29^{\circ} 18^{\prime} 28.6^{\prime \prime} \mathrm{E}$, the right bank of Paz River opposite Jordanfoss Peninsula (Norway), birch and willow forest, on old slate, 28.09.2016. - New to LPS. Previously known in MR only from Lapponia Imandrae (Urbanavichus et al., 2008) and Karelia Keretina (Zhdanov, 2011)

Placynthium asperellum (Ach.) Trevis. - Southern part of the reserve, $39 \mathrm{~km}$ SW of Nikel, $69^{\circ} 14^{\prime} 24.4$ "N, 29 $20^{\prime} 51^{\prime \prime} \mathrm{E}$, NW-oriented slopes of unnamed mountain, on calcareous rocks, 29.09.2016. - In MR this calcareous species is known from three provinces: LPS, Lapponia Imandrae and Kuusamo (Urbanavichus et al., 2008).

Protoparmelia ochrococca (Nyl.) P. M. Jørg., Rambold \& Hertel - Southern part of the reserve, $45.7 \mathrm{~km}$ SW of Nikel, $69^{\circ} 09^{\prime} 45^{\prime \prime} \mathrm{N}$, $29^{\circ} 17^{\prime} 05.7^{\prime \prime} \mathrm{E}$, eastern shore of Höyhenjärvi Lake, pine forest, on pine branch, 27.09.2016; the central part of the reserve, $40 \mathrm{~km} \mathrm{SW}$ of Nikel, 69 ${ }^{\circ} 15^{\prime} 35^{\prime \prime \prime} \mathrm{N}, 2^{\circ} 17^{\prime} 35.3^{\prime \prime} \mathrm{E}$, northern part of Chevessuolo Island, old pine forest, on pine branch, 28.09.2016. - Thallus of very small, glossy, subglobose, green-brown to chestnut brown areoles, lacking isidia; apothecia convex, almost biatorine, with disappearing margins; 1obaric acid absent. Another epiphytic species, P. oleagina (Harm.) Coppins, reported from MR by Zhdanov (2011), is distinguished by its isidiate thallus. New to MR. One of the northernmost localities in the world, the nearest in northern Europe being in the province of Nordland in Norway (Nordin et al., 2017).

PROTothelenella Leucothelia (Nyl.) H. Mayrhofer \& Poelt - Southern part of the reserve, $41.5 \mathrm{~km}$ SW of Nikel, $69^{\circ} 12^{\prime} 30.5^{\prime \prime N}, 2^{\circ} 19^{\prime} 31.8^{\prime \prime} \mathrm{E}$, the right bank of Paz River, pine forest, on thallus of Cladonia sp. growing on mosses over boulder, 28.09.2016. - New to LPS. This species was described from Lapponia Murmanica in MR (Nylander, 1866) and recently reported from Lapponia Imandrae (Urbanavichus et al., 2013).

Scytinium tenuissimum (Dicks.) Otálora, P. M. Jørg. \& Wedin - Southern part of the reserve, 42 $\mathrm{km}$ SW of Nikel, 69²'40.2”N, 29¹8'28.6”E, the right bank of Paz River opposite to Jordanfoss Peninsula (Norway), birch and willow forest, on saxicolous bryophytes, 27.09.2016. - New to LPS. Previously known in MR from three provinces: Lapponia Imandrae, Lapponia Ponojensis and Kuusamo (Urbanavichus et al., 2008).

\#SPHAERELlOTHECIUM PARMELIAE Diederich \& Etayo - Southern part of the reserve, $44.5 \mathrm{~km}$ SW of Nikel, 69¹0'12.5”N, 29 $18^{\circ} 20.7^{\prime \prime} \mathrm{E}$, eastern shore of Höyhenjärvi Lake, aspen forest, on thallus of saxicolous Parmelia omphalodes, 27.09.2016. New to LPS. Previously known in MR only from Lapponia Murmanica (Zhurbenko, 2009) and Lapponia Imandrae (Urbanavichus et al., 2013).

Stereocaulon capitellatum H. Magn. - Central part of the reserve, $32.5 \mathrm{~km}$ SW of Nikel, $69^{\circ} 17^{\prime} 22^{\prime \prime} \mathrm{N}, 29^{\circ} 27^{\prime} 19^{\prime \prime} \mathrm{E}$, cliffs on the left bank of stream from Kaskamajarvi Lake to Bossojavrre Lake, on rocks, 01.10.2016. - Included in the Red Data Book for the Murmansk region (2014). New to LPS. Previously known in MR only from Khibiny Mts. (Urbanavichus et al., 2008).

\#STIGMIDIUM LEPRARIAE Zhurb. - Southern part of the reserve, $39 \mathrm{~km}$ SW of Nikel, 69 $14^{\prime} 24.4^{\prime} \mathrm{N}$, $29^{\circ} 20^{\prime} 51^{\prime \prime} \mathrm{E}, \mathrm{NW}$-oriented slopes of unnamed mountain, on thallus of Lepraria borealis growing on saxicolous bryophytes, 29.09.2016. - New to LPS. Previously known in MR only from Lapponia Murmanica (Zhurbenko, 2009).

THELOCARPON SUPERELLUM Nyl. - Central part of the reserve, $32.5 \mathrm{~km}$ SW of Nikel, $69^{\circ} 17^{\prime} 20.7^{\prime} \mathrm{N}$, $29^{\circ} 25^{\prime} 54.9^{\prime} \mathrm{E}, \mathrm{NE}-\mathrm{spur}$ of Kalkupya Mt., pine forest, on saxicolous bryophytes, 22.08.2015. - New to LPS. This species was described from Lapponia Tulomensis by W. Nylander and only recently reported from Lapponia Imandrae (Urbanavichus et al., 2008).

Xylographa vermicularis T. Sprib. (Fig. 2). Southern part of the reserve, $45.7 \mathrm{~km}$ SW of

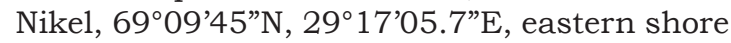
of Höyhenjärvi Lake, pine forest, on lignum of pine log, 27.09.2016. - New to Europe, recently described from the Far East of Russia (Spribille et al., 2014). Our specimen is morphologically, anatomically and chemically (confriesiic acid) in accordance with the protologue (Spribille et al., 2014). 


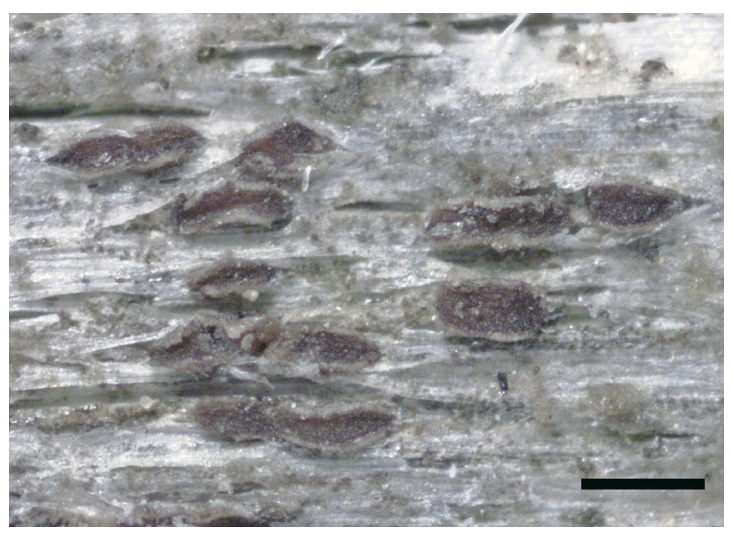

Fig. 2. Xylographa vermicularis, thallus and apothecia. Scale bar $=0.5 \mathrm{~mm}$.

\section{ACKNOWLEDGEMENTS}

We are grateful to Natalia Policarpova for organizing the expedition to the Pasvik Reserve, and to Prof. Mark Seaward who kindly corrected the English.

\section{REFERENCES}

Andersson, L., Alexeeva, N. \& Kuznetsova, E. (eds). 2009. Survey of biologically valuable forests in North-Western European Russia. Vol. 2. Identification manual of species to be used during survey at stand level. St. Petersburg. 258 pp. (In Russian).

Borovichev, E. A. \& Boychuk, M. A. 2016. Checklist of liverworts of the Pasvik State Nature Reserve (Murmansk Region, Russia). Folia Cryptogamica Estonica 53: 1-8. http://dx.doi.org/10.12697/ fce.2016.53.01

Fadeeva, M. A., Golubkova, N. S., Vitikainen, O. \& Ahti, T. 2007. Conspectus of lichens and lichenicolous fungi of the Republic of Karelia. Petrozavodsk. 194 pp. (In Russian).

Fadeeva, M. A., Dudoreva, T. A., Urbanavichus, G. P. \& Ahti, T. 2011. Lichens of the Pasvik Strict Nature Reserve (annotated checklist). Apatity. 80 pp. (In Russian).

Fadeeva, M. A., Urbanavichus, G. P. \& Ahti, T. 2013. Additions to the lichen flora of the Pasvik Strict Nature Reserve. Transactions of Karelian Research Centre of RAS. Ser. Biogeography 2: 101-104. (In Russian, English summary). http://resources. krc.karelia.ru/transactions/doc/trudy2013/ trudy_2013_2_101-104.pdf

Nordin, A., Moberg, R., Tønsberg, T., Vitikainen, O., Dalsätt, Å., Myrdal, M., Snitting, D. \& Ekman, S. 2017. Santesson's Checklist of Fennoscan- dian Lichen-forming and Lichenicolous Fungi. http://130.238.83.220/santesson/home.php (15 February 2017).

Nylander, W. 1866. Lichenes Lapponiae orientalis. Notiser Sällskap Fauna Flora Fennica Förhandlingar 8: 101-192.

Orange, A., James, P. W. \& White, F. J. 2001. Microchemical methods for the identification of lichens. London. $101 \mathrm{pp}$.

Räsänen, V. 1943. Petsamon jäkäläkasvisto. Annales Botanici Societatis Zoologicae-Botanicae Fennicae "Vanamo". 18(1): 1-110.

Red Data Book of the Murmansk Region. 2014. Kemerovo. 578 pp. (In Russian).

Spribille, T., Resl, P., Ahti, T., Pérez-Ortega, S., Mayrhofer, H. \& Lumbsch, H. T. 2014. Molecular systematics of the wood-inhabiting, lichen-forming genus Xylographa (Baeomycetales, Ostropomycetidae) with eight new species. Symbolae Botanicae Upsalienses 37(1): 1-87.

Urbanavichus, G. P. 2014. Additions to the lichen flora of Murmansk region. Bulletin of Moscow Society of Naturalists. Biological series 119(3): 77. (In Russian). http://herba.msu.ru/russian/journals / bmsn/archive/moip_2014_119_3.pdf

Urbanavichus, G. P. 2015. Lichens and lichenicolous fungi new for Russia and Murmansk Region from Pasvik Reserve. Bulletin of Moscow Society of Naturalists. Biological series 120(3): 74-75. http://herba.msu.ru/russian/journals/bmsn/ archive/moip_2015_120_3.pdf

Urbanavichus, G. 2016. Additions to the lichens and lichenicolous fungi of Pasvik Reserve, Murmansk region, Russia. Graphis Scripta 28: 8-10. http:// nhm2.uio.no/botanisk/lav/Graphis/28_1-2/ GS_28_8.pdf

Urbanavichus, G., Ahti, T. \& Urbanavichene, I. 2008. Catalogue of lichens and allied fungi of Murmansk Region, Russia. Norrlinia 17: 1-80.

Urbanavichus, G. P. \& Urbanavichene, I. N. 2008. New and rare lichens and lichenicolous fungi species for Murmansk Region from Lapland Reserve. Novitates Systematicae Plantarum Non Vascularum 42: 189-197. (In Russian, English summary). http:// www.binran.ru/files/journals/NSNR/2008_42/ NSNR_2008_42_Urbanavichus_Urbanavichene_1. pdf

Urbanavichus, G. P., Urbanavichene, I. N. \& Melekhin, A. V. 2013. The lichen flora of the Lapland State Nature Biosphere Reserve (Annotated List). Apatity. 158 pp. (In Russian).

Urbanavichus, G. P. \& Fadeeva, M. A. 2013. Addition to the lichen flora of Pasvik Reserve (Murmansk Region). Vestnik Tver State University. Ser. Biology \& Ecology 30(7): 77-84. (In Russian, English summary). http://eprints.tversu.ru/3573/1/7784Вестник_30_биология_2013.pdf

Urbanavichus, G. P. \& Fadeeva, M. A. 2014. Addition to the lichen flora of Pasvik Reserve 
(Murmansk Region). II. Vestnik Tver State University. Ser. Biology \& Ecology 2: 111-123. (In Russian, English summary). http://eprints. tversu.ru/4757 / 1/Вестник_ТвГУ._Серия_Биология_и_ экология._2014._2._С._111-123..pdf

Urbanavichus, G. P. \& Fadeeva, M. A. 2015. Lichens and lichenicolous fungi new for the Pasvik Reserve (Murmansk Region). Transactions of Karelian Research Centre of RAS. Ser. Biogeography 4: 117-121. (In Russian, English summary). http:/ / journals.krc.karelia.ru/index.php/biogeo/article/view/26

Urbanavichus, G. P. \& Fadeeva, M. A. 2016. New findings to the lichen flora of the Pasvik strict nature reserve (Murmansk Region). Transactions of Karelian Research Centre of RAS. Ser. Biogeography 3: 97-102. (In Russian, English summary). http:// journals.krc.karelia.ru/index.php/biogeo/article/view/270

Urbanavichus, G. P. \& Fadeeva, M. A. 2017. Additions to the lichen flora of the Pasvik Reserve (Murmansk region) based on records of 2015-2016. Transactions of Karelian Research Centre of RAS. Ser. Biogeography. (In press; in Russian, English summary).
Urbanavichus, G. P., Kutenkov, S. A. \& Fadeeva, M. A. 2014. New findings in Russia of Cladonia albonigra Brodo \& Ahti (Cladoniaceae, Ascomycota) from Murmansk Region. Transactions of Karelian Research Centre of RAS. Ser. Biogeography 2: 165-167. (In Russian, English summary). http:// resources.krc.karelia.ru/transactions / doc/ trudy2014/trudy_2014_2_165-167.pdf

Vitikainen, O. \& Dudoreva, T. 2003. Arctoparmelia subcentrifuga new to Europe. Graphis Scripta 14: 3-4. http://nhm2.uio.no/botanisk/lav/ Graphis/14_1/GS_14_3.pdf

Zhdanov, I. S. 2011. Contributions to the lichen flora of Kandalaksha Nature Reserve (Murmansk Region). Novitates Systematicae Plantarum Non Vascularum 45: 168-182. (In Russian, English summary). http:/ /www.binran.ru/files/journals / NSNR/2011_45/NSNR_2011_45_Zhdanov_2.pdf

Zhurbenko, M. P. 2009. Lichenicolous fungi and some lichens from the Holarctic. Opuscula Philolichenum 6: 87-120. 